\title{
Heller, Schmitt and the Euro
}

\author{
Wolfgang Streeck*
}

\begin{abstract}
Heller understood that Schmitt's 'authoritarian state' was in fact the liberal state in its pure form, weak in relation to the capitalist economy but strong in fending off democratic interventions in its operation. Had he lived, Heller would not have been surprised by the close affinities between Schmittian economic authoritarianism and postwar German ordoliberalism, as mediated by a figure like Alexander Rüstow. Neoliberalism as today we know it drew heavily on ordoliberal doctrine, in particular through Friedrich von Hayek who managed to merge it with Austrian economics into a powerful ideological force to replace Keynesianism after the 1970s. Today the European Union, especially in its incorporation as monetary union, closely follows the liberalauthoritarian template as devised by Schmitt and others in the final years of the Weimar Republic. The paper shows this with reference to the five European-level institutions that today govern the European free market while protecting it from democratic interference: the Parliament, the Council, the Commission, the European Court of Justice and the European Central Bank.
\end{abstract}

Hermann Heller's penetrating discussion ${ }^{1}$ of Carl Schmitt's project of an 'authoritarian state' ${ }^{2}$ provides us with an object lesson on the nature of liberalism and its relationship to democracy - one could also say: on the deep tensions between democracy and capitalism. What we can learn here is not at all limited to the Weltwirtschaftskrise and the final years of the Weimar Republic. Liberalism, Heller finds in Schmitt, exists in a strange, paradoxical relationship with the state and public power. The freedom of the market from state interference that defines a liberal and indeed a liberal-capitalist economy is not a state of nature but is and needs to be politically constructed, publicly instituted and enforced by state power. The depoliticised condition of a liberal economy is itself an outcome of politics, in the sense of a specific use of the authority of the state for a specific political purpose - it is a political construction that must be politically defended against the possibility

This is a commissioned article.

* Emeritus Director, Max Planck Institute for the Study of Societies, Cologne, Germany. I am grateful to Martin Höpner for constructive advice.

${ }^{1}$ H. Heller, 'Autoritärer Liberalismus?' (1933) 44 Die Neue Rundschau 289-298. See English translation in this issue.

${ }^{2}$ C. Schmitt, 'Gesunde Wirtschaft im starken Staat. Mitteilungen des Vereins zur Wahrung der gemeinsamen wirtschaftichen Interessen in Rheinland und Westfalen (Langnamverein)' (1932) 21 Neue Folge 13-32. English translation: 'Strong State: Sound Economy', in R. Cristi, Carl Schmitt and Authoritarian Liberalism (University of Wales Press, 1998), 212-232. 
of political authority falling into the hands of social forces that might use it for non-liberal, market-subverting objectives.

This is where the state and its institutions come in, as reflected in Schmitt's distinction between a 'total' and an 'authoritarian' state. In 1932, on the eve of Hitler's Machtergreifung, when Schmitt presented his project to the Langnamverein of Rhineland industrialists, the 'total state' was still identified with the 'pluralist democracy' of Weimar, a state penetrated by a variety of social groups, including the organised working class, all of which trying to make it serviceable to their particular interests. To Schmitt, this state was a weak state even it might have looked strong on account of its omnipresence and its deep interpenetration with society and economy. From the perspective of the latter, such interpenetration entails an ever-present danger of a 'distortion' of market outcomes in the name of democratic-popular-today one would say: populist - concepts of 'social justice', detracting from efficiency as well as curtailing basic rights of property. The 'total state', that is to say, is in Schmitt's dictionary of 1932 nothing else than the democratic, or more precisely, socialdemocratic interventionist welfare state. It is not yet the Behemoth, ${ }^{3}$ then waiting in the wings, the fascist total state, the Führerstaat with its Neuordnung der Wirtschaft, its Five-Year Plans, and its war economy - the total state preparing for total war and taking its economy into its own hands, at least for the time being.

Of course, when the real total state arrived, the concern Schmitt had in 1932 had become void: that its complex extensions into economy and society might be utilised by the democratic organisations of the working class to correct the distribution of wealth and income as produced by capitalist markets. Before Hitler sent the leaders of the Left to the camps, the total state still bore the risk that it might become democratic, or at least be occasionally used for democratic purposes. This was why the authoritarian state was to be preferred as long as there was still a potentially viable Left. Obviously what Schmitt called the authoritarian state was a liberal state, but calling it thus might have been misunderstood by his audience to mean a state that would also be democratic. This was definitely not what German industrialists had in mind at the time. Schmitt's authoritarian state, as Heller rightly notes, was a liberal-authoritarian state, one that was, in the classical liberal way, strong and weak at the same time: strong in its role as protector of 'the market' and 'the economy' from democratic claims for redistribution - to the point of being able to deploy the public power to suppress such claims - and weak in its relationship to the market as the designated site of autonomous capitalist profit-seeking, which government policy was to protect and if necessary expand without, however, entering it.

In an interesting way, the strong-and-weak state of liberalism-keeper of the capitalist market economy while staying out of its everyday operation-resembles how deist theology, in its Leibnizian version, imagined God: as an all-powerful clockmaker limiting himself to watching the operation of the perfect clock he has made, without intervening in it. ${ }^{4}$ After all, if he had to intervene, the clock would not be perfect. The modern state, having made space for self-equilibrating markets in accordance with the rules of economic science, cannot do better than let them

\footnotetext{
${ }^{3}$ F. Neumann, Behemoth. The Structure and Practice of National Socialism (Oxford University Press, 2nd edn, 1944).

4 For a much more profound exploration of the theological dimension of German anti-liberal liberalism, see P. Manow, 'Ordoliberalismus als ökonomische Ordnungstheologie', (2001) 29 Leviathan 179-198.
} 
run their course. Action is required only if ignorant or malicious outsiders try to break into the protected zone of market freedom, threatening to upset the benevolent free play of market forces. It is in such critical moments that the authoritarian state must show that it deserves its designation, and that it has the power and the determination to ensure that the rules of a liberal economic constitution will not just exist on paper.

Another general observation that comes to mind reading Heller and Schmitt concerns the similarities between Schmitt's 'authoritarian liberalism' and the 'ordoliberalism' of postwar Germany. What Heller and Schmitt make apparent, from opposite political positions, is the statist-authoritarian element in what was and still is normally advertised as the liberal antipode to the strong state of national socialism. ${ }^{5}$ Both Schmitt and the ordoliberals ${ }^{6}$ differ from Anglo-American liberalism in that they never believed in a market economy independent from state authority. ${ }^{7}$ To them, Leviathan was and had to be there first. They also have in common that they regard the economy, the market and capitalism as a self-driving and self-equilibrating machinery put in place by an act of politics and the state and then let go - a machinery in need of protection from uninformed or corrupt outside interference, and perhaps of being repaired once in a while from its wear and tear. The competitive advantage of ordoliberalism after 1945 was that it could be sold as a lesson learned the hard way from the statist-dictatorial Nazi regime and its war economy: from the failure, political, moral and economic, of the Behemoth. Authoritarian liberalism, which to Schmitt might still have been the second-best solution, given that a 'total state' was still too closely associated with pluralist democracy, could now, after the disaster of the dictatorial total state, become the first-best choice from the perspective of capitalism and its resurrection, given capitalism's damaged reputation after the disasters of the first half of the 20th century.

As indicated, German ordoliberalism, having inherited from Schmitt a keen awareness of the crucial role of the state in designing and protecting a capitalist economy, as well as of the risks associated with state intervention in a democracy, played a special role in the postwar political economy, both ideationally and practically. New Deal Keynesianism and the residues of the war economy in the United States were much less about 'free markets' than West German ordoliberalism,

\footnotetext{
${ }^{5}$ On the complex relationship between ordoliberalism and national socialism, as mediated by the ambivalent attitude of German Protestantism towards the Third Reich, see the masterful analysis by P. Manow, supra, fn 4.

${ }^{6}$ Who incidentally were more closely connected historically than one would perhaps expect. Schmitt's November 1932 lecture, 'Starker Staat und gesunde Wirtschaft', on which Heller commented, was preceded by a lecture by one Alexander Rüstow, economist and sociologist, titled 'Freie Wirtschaft, starker Staat' (Free Economy, Strong State), which was held in September of the same year. There, Rüstow referred to Schmitt having earlier characterised the 'total state' as a weak state: ' . . not total power, but total powerlessness ... a weakness that is unable to defend itself against the united assault of organized interests (Interessentenhaufen). The state is torn apart by greedy interests ...' Rüstow had set out in 1918 on the radical Left but then moved to the conservative Right during the Weimar Republic. Unlike Schmitt, he had to emigrate in 1933 to escape Nazi persecution. After 1945, he became one of the leading figures of German ordoliberalism. He died in 1963. On Rüstow and Schmitt, see Wikipedia http://de.wikipedia.org/wiki/Carl_Schmitt, and W. Bonefeld, Critical Theory and the Critique of Political Economy: On Subversion and Negative Reason (Bloomsbury, 2014), 180-181. On Rüstow, cf http://de.wikipedia.org/wiki/Alexander_R\%C3\%BCstow (both as read on 6 March 2015).

${ }^{7}$ For a perceptive discussion of the relationship between ordoliberalism and neoliberalism, see M. Blyth, Austerity: The History of a Dangerous Idea (Oxford University Press, 2013).
} 
which had managed to take over the Ministry of Economics for the two decades of Wirtschaftswunder. In a capitalist world fascinated with demand management and planning, the German Economics Ministry was the one place where market liberalism was more than a sectarian memory from a distant past cut off from policy. This made Germany an interesting address for 'Austrian' economists then hibernating, as an exotic sect, in the United States and Britain. The most important liaison between the two was, of course, Friedrich von Hayek, who for a few years occupied a chair at Freiburg, the academic home of the German ordoliberal school. Michel Foucault's analysis of the rise of neoliberalism ${ }^{8}$ rightly focuses on Germany rather than Anglo-America. In anchoring ordoliberalism in the German state tradition and the politics of postwar and post-Nazi Germany, Foucault might have gone back further to Schmitt and Heller, where he would have found the basic figure of thought that informed and informs liberal ideas of the economic role of state authority under capitalism - the idea, in the words of the title of a 1980s book on Margaret Thatcher, of the need of a 'free economy' for a 'strong state'.

The unique qualification of ordoliberalism for building a bridge from the authoritarian liberalism of interwar Germany, as conceived by Schmitt and analysed by Heller, to the neoliberalism that began to dismantle the postwar political economy in the 1980 s can be seen when comparing it to the economic common sense of the $1950 \mathrm{~s}$ and 1960s. The Frankfurt School of 'Critical Theory', for example, was convinced that the capitalist economy had become inseparably merged into the state, which in the process had turned into the dominant institutional complex in contemporary society. ${ }^{10}$ After 'the end of laissez-faire', the place of liberal capitalism was supposed to have been taken by three competing economic systems, communism, fascism and New Deal democracy. All of them were seen as deeply politicised, democratically or not, with markets having given way to large, bureaucratically organised corporate monopolies closely affiliated with the bureaucracies of the state. In its own way, each of the three systems resembled Schmitt's total state, with the New Deal variant carrying the risk of a democratic subversion of market justice, under the influence of pluralist democracy. Schmitt and Heller would have recognised this, from their opposite points of view, and both might have seen the possibility, and indeed the probability, of capitalist pressures for a return to the market: that is, for a new politics carving out a space for free markets sustained and guarded by state authority while protected from egalitarian-democratic infringement. Such pressures for, as I have put it, ${ }^{11}$ a Hayekian succession to the Keynesianism social welfare state - the replacement of growth through egalitarian redistribution by growth through stronger incentives for the winners and more severe punishment for the losers - were easily conceptualised in ordoliberal terms, informed as ordoliberalism was, all the way from Schmitt to Hayek, on the intricate dialectic of state strength and state weakness in a liberal order: strong in fending off democratic-political claims for market correction, weak in

${ }^{8}$ M. Foucault, The Birth of Biopolitics: Lectures at the College de France, 1978-1979 (Palgrave Macmillan, 2008).

${ }_{9}$ A. Gamble, The Free Economy and the Strong State (Macmillan, 1998).

${ }^{10}$ On this, see for example F. Pollock, 'Staatskapitalismus', in H. Dubiel and A. Söllner (eds), Wirtschaft, Recht und Staat im Nationalsozialismus (Europäische Verlagsanstalt, 1981), at 81-109; also in Stadien des Kapitalismus (Beck, 1975). English translation, 'State Capitalism: Its Possibilities and Its limits', in A. Arato and E. Gebhardt (eds), The Essential Frankfurt School Reader, 71-94. The text was originally published in 1941.

${ }^{11}$ W. Streeck, Buying Time: The Delayed Crisis of Democratic Capitalism (Verso Books, 2014). 
leaving the governance of the economy to the self-regulating clockwork of the market, as put in place and preserved by political authority.

So far on the general idea. Today's post-democratic, or better perhaps a-democratic, Hayekian capitalism, after the victory, or almost-victory, of neoliberalism, may be regarded as a historically updated version of ordoliberalism. What it has in common with it is the insulation of a politically instituted market economy from democratic politics, an insulation on account of which both the neoliberal state and the neoliberal economic regime qualify as authoritarian in the sense of Schmitt and Heller. I said historically updated since the neoliberal configuration can do without a background memory of fascist totalitarianism and the catastrophes associated with it; its background are the trente glorieuses of the capitalist welfare state. Nor does it depend, as did the authoritarian state project of the early 1930s, on a von Papen pro-capitalist state-of-emergency would-be dictatorship. ${ }^{12}$ Today the neutralisation of democracy and the recalibration of state power in the service of a market economy with politically constructed political autonomy do not primarily take place through repression but by moving the governance of the political economy to a level where democracy cannot follow, and to institutions constitutionally designed to be exempt from political contestation, with legally enshrined missions, whose authority does not come out of gun barrels but is derived from 'scientific' economic theory. As democratic politics is in the process emptied of political-economic content, the vacated public space is re-dedicated to consumerist politainment.

Understanding how the politically engineered depoliticisation of contemporary European capitalism works requires detailed attention to its institutional framework. One aspect of it is the relocation of political-economic decisions from the national to a new, specifically constructed international level, into the hands of international organisations: to an institutional context, in other words, that unlike the nation-state was consciously designed not to be suitable for democratisation. ${ }^{13}$ Ideologically, the political-economic pre-emption of the nation-state - of democratic national institutions in favour of technocratic supranational ones-makes use of certain positive normative connotations of internationalism, especially on the Left, to fill the role that in Schmitt's authoritarian nation-state was to be filled, presumably, by appeals to patriotic discipline. Using Left internationalism for Left disempowerment is a particular ironic method to de-democratise a capitalist political economy, especially if deployed by the Left itself. It comes with a moral denunciation of borders and protectionism tout cours of in the name of a misunderstood cosmopolitanism, identifying 'globalisation' with liberation, not just of capital, but of life in general. To dispel concerns about a possible hegemony of global markets over democratic participation, and with it of the economic over the social, pipe dreams of a future global or, at a minimum, continental democracy are offered as baits for Left idealists: promises of a better future in which international democracy will have regained control over international capital, if not tomorrow then the day after tomorrow.

To repeat, the language of authority being out of fashion in today's Euro-Europe, it must be replaced with a mixture of technocratic claims to superior expertise and resigned submission to the 'realities' of 'globalisation'. Since this may not always suffice, the architects of the neo-authoritarian political-cum-economic regime find it

\footnotetext{
12 As proclaimed by the von Papen sycophant, Walther Schotte in Der Neue Staat (Neufeld \& Henius, 1932), to which Heller refers.

13 P. Mair, Ruling the Void: The Hollowing of Western Democracy (Verso, 2013).
} 
necessary to offer the public a preview of international democracy, a trailer of things to come, in the shape of the so-called European Parliament with its 'European elections'. Of course, that 'parliament' has no executive to control; it lacks the right of legislative initiative; and it cannot change the constitution of 'Europe', if only because there is no such thing since the rules of the European game are written by the national executives in the form of unbelievably complex and even for specialists entirely unreadable international treaties. ${ }^{14}$ Just as there is no governing majority in the Parliament, there is no opposition either: voters who are sceptical or do not care about the European construction abstain from voting, and indeed in rising numbers. To the extent that those who do vote elect what the Euro-establishment calls 'antiEuropeans', their representatives are mercilessly sidelined in the 'Parliament's' everyday operation, so much so that during the five years between elections one never hears of them. For decades now, the business of the 'European Parliament' was managed by a centrist Grand Coalition, which functions as a powerful lobby for the relocation of decision-power from national democracies to a 'Europe' immunised against democratic expectations and devoid of opportunities for, in Schmitt's terms, 'democraticpluralist' interference with the free market capitalist clockwork.

Europeanisation today is by and large identical with a systematic emptying of national democracies of political-economic content, cutting off the remnants of potentially redistributive 'social' democracy, housed in nation-states, from an economy that has long grown beyond national borders into a, politically constructed and contracted, 'Single Market'. ${ }^{15}$ Where there are still democratic institutions in Europe, there is no economic governance any more, lest the management of the economy is invaded by market-correcting non-capitalist interests. And where there is economic governance, democracy is elsewhere. Since this might become a problem if it became all-too-obvious, the champions of the Brussels non-parliament took for last year's 'European election' - the first since the European ramifications of the global 'financial crisis' were felt - to some of the same devices that have long been used in national democracies to make voters believe they have a choice. ${ }^{16}$ Rather than asking for a vote for or against 'Europe' or the Euro, the leaders of the two centrist blocs, the centreright and the centre-left, who had never been able to discover even the slightest difference in their interests and political persuasions, decided to personalise the election and present themselves as Spitzenkandidaten competing for the presidency of the European Commission, which of course is filled not by the 'Parliament' but by Member State governments - an exercise in Fassadendemokratie (Habermas) if there ever was one. That they never managed to explain where they disagreed, even more so than their social-democratic and Christian-democratic equivalents in national politics, obviously did not bother them, nor did the fact that in several countries their competition was not even noticed. In any case, voter turnout declined once again, to $43 \%$,

14 The literature on the European 'democratic deficit' is unending. Contributing authors are divided between those who feel they should offer institutional remedies for it, and those who do not because they consider the absence of democracy in 'Europa' to functionally necessary: either to make European unity possible or to promote neoliberal capitalism, or one in pursuit of the other.

15 On this and the following, see F. W. Scharpf, 'Monetary Union, Fiscal Crisis and the Pre-Emption of Democracy', (2011) 9 Zeitschrift für Staats- und Europawissenschaaften 163-198; 'Monetary Union, Fiscal Crisis, and the Disabling of Democratic Accountability', in A. Schäfer and W. Streeck (eds), Politics in the Age of Austerity (Polity, 2013), at 108-142.

${ }^{16}$ On the European election of 2014 and its aftermath, see S. Watkins, 'The Political State of the Union', (2014) 90 New Left Review 5-25. 
and no less than $15 \%$ of those who bothered to vote voted for parties classified as 'anti-European' by the 'true Europeans'. Regardless, the Spitzenkandidat whose party won $30 \%$ of the seats (ie the backing of roughly $13 \%$ of the electorate) claimed victory, while his nominal opponent, commanding $25 \%$ of the seats, rushed to support his demand for the office of Commission President, in the act claiming for himself, as it turned out, in vain, the vice-presidency.

Next to the so-called European Parliament, there are four more political institutions that run, maintain and protect the politically depoliticised liberal-capitalist market of Europe united by a common currency. In discussing them briefly, I will pay particular attention to how they match the model of Schmitt's 'authoritarian state' in shielding the capitalist economy from the spectre of 'democratic pluralism'.

1. The European Council. It consists of the heads of national governments and is supported by various councils of ministers, especially of finance and foreign affairs. Of particular importance here is the so-called Euro Group of the finance ministers of European Monetary Union (EMU) Member States. The Council is the legislative and the executive of the multinational European non-state in one, a combination that is by itself a defining feature of an authoritarianism regime. The Council also serves to keep national democratic institutions, especially national parliaments, at bay in that it operates through negotiations, typically in secret, between the governments of sovereign states. Once a decision has been reached, it is near impossible for national publics and their representatives to undo it, an effect that has been studied in various contexts under the heading of multilevel diplomacy. ${ }^{17}$ Not only is it unlikely that all countries involved will feel equally concerned, but reopening what will typically be a complex package deal may entail unknown risks, with uncertain and asymmetric outcomes. Governments will bring this to bear in national ratification debates and find their power increased by it, also because non-ratification would impair their standing with the other governments and thereby weaken the country's position in future negotiations.

Another consequence of the primacy of the Council in European economic governance is that it redefines class conflicts as international conflicts, turning distributional issues between classes into international issues. ${ }^{18}$ This not only encourages cross-class coalitions at the national level, but it also mitigates economic conflicts as it envelopes them into larger issue packages, hands them over to diplomats, and above all entangles them with issues of international peace. Diplomacy thus takes the place of class struggle, and international cooperation takes precedence over social justice as long as repressed class conflicts can be prevented from returning in the form of international hostilities. Even then, however, the capitalist market economy will likely remain shielded from egalitarian correction, for example by economically stronger nations defending their interest by drawing on the toolkit of national sovereignty.

Moreover, the more diverse a multinational regime in terms of national economic structures and interests, the less likely it is that its governing body will be able to take discretionary measures to correct the outcome of markets. That federations of states can best agree on liberating their economies from state intervention-ie on what contemporary political science has called 'negative integration'19 — has been pointed

\footnotetext{
${ }^{17}$ P. Evans, H.K. Jacobson and R.D. Putnam (eds), Double-Edged Diplomacy: International Bargaining and Domestic Politics (University of California Press, 1993).

18 Streeck, supra, fn 11, 90ff.

19 F.W. Scharpf, 'Negative and Positive Integration in the Political Economy of European Welfare States',
} 
out by Friedrich von Hayek as early as $1939 .{ }^{20}$ International federation, so Hayek claimed, will be needed in the future to restore and preserve international peace, but a federation that fails to integrate its economy will not stand, and economic integration among countries both different and equal can proceed only in the form of market integration: the institutionalisation of a single market free from state intervention, because Member States will not be able to agree anything other than that. Hayek's 1939 article builds a bridge between Austrian economics, Schmitt's interwar 'authoritarian liberalism', German postwar ordoliberalism and the neoliberalism of EMU since the 1990s.

2. The European Commission. From early on, the Commission has aspired to establishing itself as the executive branch of a supranational European superstate, similar to the 'European Parliament' claiming the status of a European legislature. Events since the 2008 crisis, however, have confirmed and indeed cemented the predominance of the Council, arresting the Commission in its role as a bureaucratic agency charged with implementing Council decisions and overseeing member countries' adherence to the treaties. While subservient to the Council, ${ }^{21}$ however, the Commission can and does use its administrative powers to protect the Single Market by preventing Member States from protecting their national economies, as well as national institutions like labour law that provide workers with collective political capacity. Basically, the institutional interest of the Commission in safeguarding and extending its powers and functions is best served by devoting its agency to liberating national economies from national political market distortion, democratic as it may be, thereby advancing the integration of the European economy in the form of a politically constructed and safeguarded common market cleansed of national and unimpeded by supranational pluralist democracy.

3. The European Court of Justice (ECJ). A court is an authoritative institution, and a de facto constitutional court like the ECJ charged as a last instance with interpreting the law of the land may even be considered an authoritarian one. This should be all the more so in the absence of a true parliament by which it could be overruled. In fact, the real legislator facing the ECJ, the Council, typically requires unanimity to correct a court decision, and sometimes even the unanimous revision of an international treaty. The ECJ's original normative capital, as is well known, was competition law of the kind developed by the German ordoliberal school. The court has continuously extended that capital, by using its authority to institute competitive markets wherever an opportunity for this arose and identifying them with the so-called four freedoms: the free circulation of goods, services, capital and labour in the Union. Like the Council and the Commission, the Court operates on the general premise that it is the mission of 'Europe' to expand the institutional space for free markets and fend off whatever attempts may be made to contain or distort markets, nationally as well as internationally. The neoliberal, pro-market bias in ECJ jurisdiction has long been noted, and so has the tactical shrewdness

in G. Marks et al. (ed), Governance in the European Union (Sage, 1996), at 15-39.

${ }^{20}$ F.A. Hayek, 'The Economic Conditions of Interstate Federalism', in F. Hayek (ed), Individualism and Economic Order (Chicago University Press, 1980), at 255-272 (first published in 1939).

${ }^{21}$ Martin Höpner ('Wie der Europäische Gerichtshof und die Kommission Liberalisierung durchsetzen: Befunde aus der MPIfG-Forschungsgruppe zur Politischen Ökonomie der europäischen Integration', (2014) MPIfG Discussion Papers 14/8, available at http://www.mpi-fg-koeln.mpg.de/pu/mpifg_dp/dp148.pdf) allows a more independent role for the Commission, in particular for the time before the crisis. 
with which the ECJ pursues its agenda. ${ }^{22}$ Having established early on the principle of 'supremacy and direct effect' of European law, including of course its own rulings, the ECJ commands powerful tools to intervene into national political economies and impose on them what is essentially a liberal and indeed neoliberal economic constitution, protected from democratic politics partly by design and partly by default, in any case exactly as envisaged by both German ordoliberal doctrine and Schmitt's 'authoritarian liberalism'.

4. The European Central Bank (ECB). The ECB is the kingpin of the EMU, and indeed its sovereign. While other central banks are embedded in a state with coextensive jurisdiction and have to face a government and a public at the same territorial and political level, the currency and the common market the ECB runs are stateless (as is, essentially, the legal system governed by the ECJ). This makes the ECB the most independent central bank in the world, and its monetary regime the most depoliticised. Unlike Keynesian money, the euro is nothing but a means of exchange and a store of value; it is in particular not suitable for democratic market correction, for example in pursuit of full employment. European money, as conceived in the treaties that created it, is Austrian, ordoliberal and neoliberal money.

Indeed, there is hardly an institution that corresponds more closely to the ideal of authoritarian liberalism than the ECB. EMU, with its 'Single Market' and minimalist institutional furniture, looks conspicuously like an ideal realisation of Schmitt's 'authoritarian state' some eighty years after its conception. The legitimacy of its core institution, the ECB, rests exclusively on its supposed technical expertise with respect to what kind of public policy a free market economy requires if it is to remain one. In theory, this is very little, while in practice it can easily become very much. On the surface, the ECB's mandate is simply to provide for a desirable rate of inflation for the combined economy of its Member States and ensure the health and viability of their financial and payment systems. Since the national political economies that are part of EMU are historically governed by diverse institutions, however, they tend to respond differently to the ECB's money regime and monetary policy. If this raises the possibility of the common currency failing, as it did in the succession of crises since 2008, the ECB, being the only institution in charge of EMU as a whole, is forced or feels free to do 'whatever it takes' to preserve it. ${ }^{23}$ Who would not be reminded of Carl Schmitt's definition of the state of emergency, the Ausnahmezustand, being die Stunde der Exekutive, the hour of the executive when Not kennt kein Gebot, when the sovereign is entitled and proves himself as such in being able to suspend the law and use whatever means available, legal or extralegal, to secure the survival of the community ${ }^{24}$

${ }^{22}$ B. Werner, Der Streit um das VW-Gesetz: Wie Europäische Kommission und Europäischer Gerichtshof die Unternehmenskontrolle liberalisieren (Campus, 2013).

23 The now famous phrase used by the president of the ECB in a meeting with financial investors in London, on 26 July 2012, when asked what the ECB would do to keep the Euro alive. He continued: 'And believe me, it will be enough'. See 'Speech by Mario Draghi, President of the European Central Bank at the Global Investment Conference in London, 26 July 2012', available at http:// www.ecb.europa.eu/press/key/date/2012/html/sp120726.en.html.

24 C. Schmitt, Politische Theologie. Vier Kapitel zur Lehre von der Souveränität (Duncker und Humblot, 1922); English translation: Political Theology. Four Chapters on the Concept of Sovereignty (Chicago University Press, 1985). On this, see also C. Jorges, 'Europe's Economic Constitution in Crisis and the Emergence of a New Constitutional Constellation', in J. Fossum and A. J. Menéndez (eds), The European Union in Crises or the European Union as Crises? (ARENA, 2014), at 279-334. 
For several years now, the ECB has routinely been acting extra legem to fill the political vacuum created at the centre of EMU by its founders, with the intention to build Euroland into the a-political capitalist market economy of neoliberalism. ${ }^{25} \mathrm{ECB}$ intervention, on the surface limited to stabilising the euro at a targeted inflation rate and keeping payment systems functional, and legitimate only with reference to this narrow mandate, has penetrated deeply into national institutional arrangements and political settlements to 'reform' them, so as to adjust them to the common neoliberal money regime - so as to put an end, in the name of sound money, to previous national practices of adjusting the money regime to national political settlements, in particular to politically negotiated and nationally institutionalised ideas of market-correcting social justice.

Together with the Council, the Commission and the ECJ, but if need be also without them, the ECB has developed into the de facto government of the biggest economy on earth, a government entirely shielded from 'pluralist democracy' that acts, and can only act, as the guardian and guarantor of a liberal market economy. Since the crisis of 2008, which is of course far from over if it ever will be, the Bank has acquired wide-ranging capacities to discipline the sovereign states and societies in and under its jurisdiction to make them pay proper respect to the rules of a neoliberal money-cum-market regime. Today, the ECB can at its discretion withhold liquidity from the banking systems of states that refuse to follow its precepts as to their public finances, the size and composition of their public sectors, and even the structure of their wage-setting systems. States and governments that do not 'reform' themselves in line with capitalist rectitude, and thereby fail to earn the confidence of international haute finance, can be punished in a broad variety of ways - while states that carry out institutional reforms as promoted by the Bank can be rewarded, even by the ECB printing fresh money for them, in violation or circumvention of EMU treaties. ${ }^{26}$ Given the jurisdictional asymmetry between the ECB and the EMU member countries, as well as the absence of an equally effective political counterpart at the level of the EMU as a whole, the ECB is the ideal dictator - the only agent capable of taking decisive action-when it comes to crisis management, for example in the case of a Member State defaulting. The same holds for making member countries converge on the model of neoliberal financialised capitalism, in adaptation to the requirements of a common, one-size-fits-all monetary regime in good standing with 'financial markets'. The 'authoritarian state' as creator and protector of 'authoritarian liberalism' has arrived.

${ }^{25}$ This precedes the crisis, and so does the insight of quite a few perceptive observers that the ECB, the way it is instituted, is a continuing drag on democracy in Europe. See, for example, S. Berman and K.R. McNamara, 'Bank on Democracy', (1999) 78 Foreign Affairs 2-8.

${ }^{26}$ For example, by dressing up the support of national banking systems and the extension of credit to governments running deficits (with strict conditions as to neoliberal 'reforms' attached) as monetary policy. 